Elena PIOTROWSKA

Toxicology

\title{
EFFECT OF SELECTED ORGANOPHOSPHATE INSECTICIDES IN SUBLETHAL CONCENTRATIONS ON RAINBOW TROUT SALMO GAIRDNERI RICH.
}

\section{WPE YW SUBLETALNYCH STĘŻEN WYBRANYCH INSEKTYCYDÓW FOSFOROORGANICZNYCH NA PSTRĄGA TĘCZOWEGO - SALMO GAIRDNERI RICH.}

\author{
Institute of Ichthy ology and Fisheries \\ Olsztyn
}

\begin{abstract}
Comparative studies on effects of CVP and BVP insecticides in sublethal concentrations on young rainbow trout (Salmo gairdneri Rich.) were carried out under laboratory conditions. The insecticide effect was inferred from enzymatic and haematologic analyses. One experiment involved a 14-day exposure to insecticide concentrations corresponding to $5 \%$ of $96-\mathrm{h} \mathrm{LC}_{50}$, followed by the brain acetylcholinesterase, blood peroxidase and catalase activity assessment and determination of haematologic indices. The other experiment involved observing changes in the brain acetylcholinesterase activity over 30 days following the $24-\mathrm{h}$ exposure to concentrations corresponding to $50 \%$ of $24-\mathrm{h} \mathrm{LC}_{50}$.
\end{abstract}

\section{INTRODUCTION}

The previous paper by the same author (Piotrowska, 1980) reported results of the studies on acute toxicity $\left(\mathrm{LC}_{50}\right)$ and effects of lethal concentrations of CVP and BVP insecticides on selected enzymes and haematologic indices of rainbow trout. In present paper, the effect of sublethal concentrations of these insecticides are compared basing on 
changes in enzymatic activity and haematologic indices. The observations can contribute to a better understanding of mechanisms of the insecticide toxic on a fish organism.

\section{MATERIAL AND METHODS}

The studies were carried out on rainbow trout (Salmo gairdneri Rich.) individuals aged $1+$, showing a good condition and health, measuring about $18 \mathrm{~cm}$ and weighing about $65 \mathrm{~g}$.

Test solutions were prepared by dissolving technical concentrates of CVP (0,0-diethyl0-1-(2,4-dichlorophenyl)-2-chlorvinyl phosphate) and BVP (0,0-diethyl-0-1-(2,4-dichlorophenyl)-2- bromvinyl phosphate) in acetone.

The experiments were run in constantly aerated $250 \mathrm{dm}^{3}$ aquaria fed with lake water. During the exposure, the toxic solutions were changed daily; after the exposure the constant flow of water through the aquaria was maintained.

The water oxygen content, temperature, and $\mathrm{pH}$ were determined daily during the study period (Table 1). A full set of physicochemical assays was carried out once during each experiment (Table 2).

Two kinds of experiments were performed: one (Experiment I) involved enzymatic and haematologic analyses after a 14-day exposure of the fishes to the insecticide concentrations corresponding to $5 \%$ of $96-\mathrm{h} \mathrm{LC}_{50}$ (Table 3), while in the other (Experiment II) changes in the brain acetylcholinesterase were followed directly after a 24-h exposure to the insecticide concentrations corresponding to $50 \%$ of $24 \mathrm{~h} \mathrm{LC}_{50}$ and 30 days after the exposure (Fig. 1).

The acetylcholinesterase (AChE) activity was determined using Weiss (1958) modification of Hestrin's (1949) procedure; the blood peroxidase activity was determined using Bach and Zubkova's guaiacol technique (Metelev, 1971), while the manganometric technique was used to determine the blood catalase activity. Routine techniques were

Table 1

Oxygen content, temperature, and $\mathrm{pH}$ of water

\begin{tabular}{|l|c|c|c|c|c|c|}
\hline \multirow{2}{*}{$\begin{array}{l}\text { Experiment } \\
\text { and season }\end{array}$} & \multicolumn{2}{|c|}{$\begin{array}{c}\text { Oxygen content } \\
\left(\mathrm{mg} \mathrm{O}_{2} / \mathrm{dm}^{3}\right)\end{array}$} & \multicolumn{2}{|c|}{$\begin{array}{r}\text { Water temperature } \\
(\mathrm{O} C)\end{array}$} & \multicolumn{3}{c|}{ Water $\mathrm{pH}$} \\
\cline { 2 - 7 } & range & mean & range & mean & range & mean \\
\hline $\begin{array}{l}\text { Experiment I } \\
\text { Spring }\end{array}$ & $8.0-11.0$ & 9.2 & $9.0-11.0$ & 9.5 & $7.4-7.6$ & 7.5 \\
\hline $\begin{array}{l}\text { Experiment II } \\
\text { Winter }\end{array}$ & $8.0-10.0$ & 8.4 & $6.5-8.0$ & 7.7 & $7.4-7.6$ & 7.5 \\
\hline
\end{tabular}


Physico - chemical composition of water

\begin{tabular}{|l|c|c|}
\hline \multirow{2}{*}{ Parameters } & \multicolumn{2}{|c|}{ Experiment and month } \\
\cline { 2 - 3 } & $\begin{array}{c}\mathrm{I} \\
\text { April }\end{array}$ & $\begin{array}{c}\text { I I } \\
\text { January }\end{array}$ \\
\cline { 2 - 3 } Total hardness $(\mathrm{mval})$ & 3.24 & 2.89 \\
COD $\left(\mathrm{KMnO}_{4}\right)\left(\mathrm{mgO}_{2} / \mathrm{dm}^{3}\right)$ & 10.0 & 8.8 \\
Conductivity $\left(\mu \mathrm{S} / \mathrm{cm}^{3}\right)$ & 338 & 362 \\
Nitrogen as: $\mathrm{N}-\mathrm{NH}_{4}\left(\mathrm{mg} / \mathrm{dm}^{3}\right)$ & 0.06 & 0.00 \\
$\mathrm{~N}^{3} \mathrm{NO}_{2}\left(\mathrm{mg} / \mathrm{dm}^{3}\right)$ & 0.020 & 0.000 \\
$\mathrm{~N}-\mathrm{NO}_{3}\left(\mathrm{mg} / \mathrm{dm}^{3}\right)$ & 0.20 & 0.36 \\
Total nitrogen $\left(\mathrm{mg} \mathrm{N}^{3} / \mathrm{dm}^{3}\right)$ & 0.52 & 0.46 \\
Phosphates as $\mathrm{P}-\mathrm{PO}_{4}\left(\mathrm{mg} / \mathrm{dm}^{3}\right)$ & 0.036 & 0.028 \\
Total phosphorus $\left(\mathrm{mg} \mathrm{P}^{3} / \mathrm{dm}^{3}\right)$ & 0.080 & 0.054 \\
Chlorides $\left(\mathrm{mg} \mathrm{Cl}^{3} \mathrm{dm}^{3}\right)$ & 14.0 & 16.0 \\
Sulphates $\left(\mathrm{mg} \mathrm{SO}_{4} / \mathrm{dm}^{3}\right)$ & 12.2 & 16.4 \\
Silicates $\left(\mathrm{mg} \mathrm{SiO} / \mathrm{dm}^{3}\right)$ & 7.6 & 9.2 \\
Total iron $\left(\mathrm{mg} \mathrm{Fe} / \mathrm{dm}^{3}\right)$ & 0.18 & 0.09 \\
\hline
\end{tabular}

employed for the haematologic analyses (Klontz and Smith, 1968; Blaxhall and Daisley 1973).

The results of the enzymatic and haematologic analyses were treated statistically with Fisher's F test; additionally, 2-way ANOVA was performed for results from Experiment II, which allowed to compare effects of the two insecticides on the AChE activity dynamics after the exposure.

\section{RESULTS AND DISCUSSION}

Several characters tested showed highly significant changes after a 14-day exposure of fishes to sublethal concentrations of CVP and BVP (Table 3).

Most marked was the drop in the AChE activity down to $72 \%$ (28\% inhibition). and $86 \%$ (14\% inhibition) for CVP and BVP, respectively. A stronger acetylcholinesterase effect of CVP proved be statistically significant. No external symptoms of nervous disorders were observed.

Metelev and Osetrov (1968) have expressed the opinion that a 20-30\% inhibition of the $\mathrm{AChE}$ activity brings about a slight intoxication of fish.

Many authors failed to observe external symptoms of organophosphate intoxication in fish showing an $\mathrm{AChE}$ inhibition similar to these recorded in current studies. Williams and 
Sova (1966) who analysed the AChE activity in Brevoortia tyrannus and Micropogon undulatus, caught in a river polluted with anti-cholinesterase compounds, failed to observe symptoms of disorders accompanying the $\mathrm{AChE}$ activity decrease down to mean Values of $83.5 \%$ (16.5\% inhibition) and $64.2 \%$ (35.8\% inhibition). Post and Leasure (1974), when dealing with effects of sublethal concentrations of malathion on three fish species, rainbow trout included, after a 7 to 10-day exposure, analysed the physical activity index and found the $\mathrm{AChE}$ activity to drop by $18.5 \%$, which resulted in the index decrease by as little as $2.3 \%$. This result explains indirectly the lack of visible symptoms of detrimental effects of insecticides on fishes in the present study. The lack of any intoxication symptoms in six fish species (including the common Cyprinus carpio and Lebistes reticulatus) subject to a long-term exposure to organic phosphorus pesticides (10 months at $0.1 \mathrm{ppm}$ methylparathion and $0.01 \mathrm{ppm}$ malathion) is reported also by Rehnwoldt et al. (1977) who found $16-35 \%$ reduction in the brain $\mathrm{AChE}$ activity in various species.

It is obvious that lack of any visible disorders in fish behaviour cannot be taken as a proof of harmlessness of the organophosphate pesticides used over the exposure periods. Studies on the AChE reactivation made by Post and Leasure (1974) give evidence to this statemant. Post and Leasure have found that - as to the enzyme activity - it takes a rather long time to reach its normal value (about 35 days for rainbow trout). On the other hand, Weiss (1961) is of the opinion that a prolonged retum-to-normal time suggests an on-going or irreversible cholinesterase inhibition.

When discussing the brain $\mathrm{AChE}$ activity in the experiment the report by Weiss and Gakstatter (1964) should be taken into account. This report deals with changes in the AChE activity in Lepomis macrochirus and Carassius auratus exposed for 14 days to solutions of 13 phospho-organic pesticides of low concentration $\left(0.0001-0.01 \mathrm{mg} \mathrm{dm}^{-3}\right)$. When a high sensitive species is chosen, such as for instance Lepomis macrochirus, it is possible to show a significant decrease in the AChE activity after a 15-day exposure to those compounds in concentrations of $0.001 \mathrm{mg} \mathrm{dm}^{-3}$.

Results of haematologic tests (Table 3) support the conception of the evident effect of CVP and BVP on rainbow trout in the experimental system studied. CVP was found to bring about significant changes: a decrease in both the haematocrit and erythrocyte) leukocyte ratio and an increase in the erythrocyte haemoglobin content (MCHC). BVP was found to have a stronger influence on the fish blood by bringing about highly significant changes in the haematologic indices as compared to both the control and CVP-affected individuals. The blood of those fishes exposed to BVP showed the lowest haemoglobin content, the highest leukocyte count, the lowest erythrocyte/leukocyte ratio and the lowest value of $\mathrm{MCH}$ (mean erythrocyte haemoglobin content by weight) and $\mathrm{MCHC}$ (mean erythrocyte haemoglobin concentration).

It is assumed that some of these changes can be understood as a defence reaction against the toxic agent. In particular, it proves to be true for $\mathrm{MCHC}$ increase and the increase in leukocyte count in case of CVP and BVP, respectively. 
Activity of enzymes and haematological indices of rainbow trout (S. gairdneri Rich.) after 14-day exposure to sublethal concentrations of insecticides

\begin{tabular}{|c|c|c|c|c|}
\hline \multirow[t]{2}{*}{ Parameters under study } & $\begin{array}{c}\begin{array}{c}\text { Control group } \\
K \\
\mathrm{n}=75\end{array} \\
\end{array}$ & $\begin{array}{c}\text { Experimental group } \\
\text { CVP } \\
n=50\end{array}$ & $\begin{array}{c}\text { Experimental group } \\
\text { BVP } \\
\mathrm{n}=50\end{array}$ & \multirow[t]{2}{*}{$\begin{array}{l}\text { Highly significant } \\
\text { and significant* } \\
\text { differences }\end{array}$} \\
\hline & $\bar{x} \pm S_{\bar{x}}$ & $\bar{x} \pm S_{\bar{x}}$ & $\bar{x} \pm S_{\bar{x}}$ & \\
\hline $\begin{array}{l}\text { Brain AChE } \\
\text { (uM ACh/mg brain/h) }\end{array}$ & $1.43+0.13$ & $1.03 \pm 0.14$ & $1.23 \pm 0.11$ & K-CVP, K-BVP, CVP-BVP \\
\hline $\begin{array}{l}\text { Blood peroxidase } \\
\text { (guaiacol units) }\end{array}$ & $1.72 \pm 0.21$ & $1.67 \pm 0.20$ & $1.66 \pm 0.25$ & - \\
\hline $\begin{array}{l}\text { Blood catalase } \\
\text { (activity units) }\end{array}$ & $3.9 \pm 0.5$ & $4.0 \pm 0.6$ & $3.8 \pm 0.6$ & - \\
\hline Haemoglobin (g\%) & $8.4 \pm 0.9$ & $8.2 \pm 0.8$ & $7.7 \pm 1.0$ & - $\quad \mathrm{K}-\mathrm{BVP}, \mathrm{CVP}-\mathrm{BVP}$ \\
\hline Haematocrit (\%) (PCV) & $39.0 \pm 3.3$ & $36.5 \pm 3.0$ & $38.0 \pm 4.0$ & K-CVP $\quad-$ \\
\hline Erythrocytes $\left(\times 10^{6} / \mathrm{mm}^{3}\right)$ & $1.13 \pm 0.14$ & $1.08 \pm 0.12$ & $1.12 \pm 0.19$ & $-\quad-$ \\
\hline Leukocytes $\left(\times 10^{3} / \mathrm{mm}^{3}\right)$ & $4.7 \pm 2.0$ & $5.4 \pm 2.2$ & $13.1 \pm 6.7$ & $-\quad \mathrm{K}-\mathrm{BVP}, \mathrm{CVP}-\mathrm{BVP}$ \\
\hline Lymphocyrtes (\%) & $94.2 \mp 4.2$ & $92.3 \pm 6.7$ & $92.1 \pm 3.8$ & - \\
\hline Red (white cell ratio) & $294 \mp 144$ & $230 \pm 90$ & $108 \pm 54$ & K-CVP, K-BVP, CVP-BVP \\
\hline $\operatorname{MCV}\left(\mu M^{3}\right)$ & $351 \pm 41$ & $344 \pm 41$ & $348 \pm 63$ & $-\quad-\quad-$ \\
\hline $\mathrm{MCH}(\mathrm{pg})$ & $75 \pm 10$ & $77 \pm 9$ & $71 \pm 14$ & - K-BVP*, CVP-BVP* \\
\hline $\mathrm{MCHC}(\%)$ & $21.2+1.5$ & $22.5+1.6$ & $20.2+1.8$ & $\mathrm{~K}-\mathrm{CVP}, \mathrm{K}-\mathrm{BVP}, \mathrm{CVP}-\mathrm{BVP}$ \\
\hline
\end{tabular}


During a long-term exposure of carp to low concentrations of Phthalophos (Imidan), Kanaev et al. (1977) found a decrease in haemoglobine content, erythrocyte count, and haematocrit, the changes being statistically significant only at a concentration corresponding to $10 \%$ of $48 \mathrm{~h} \mathrm{LC}_{50}$, which resulted in a considerable mortality during a 2 -month exposure. Concentrations equal to $1 \%$ and $2 \%$ of $48 \mathrm{~h} \mathrm{LC}_{50}$ have had no lethal effect during the experiment. However, poorer feeding and in some individuals slight external intoxication symptoms were observed. Moreover, a considerable inhibition of the brain $\mathrm{AChE}$ was found at the lowest concentration used $\left(0.05 \mathrm{mg} \mathrm{dm}^{-3}\right)$, corresponding to approximately $1 \%$ of $48 \mathrm{~h} \mathrm{LC}_{50}$. The enzyme activity fell down by $41-85.6 \%$ after 2-6 days of exposure, no clinical symptoms being observed. It is noteworthy that the phenomenon had not stopped on the termination of exposure to the lethal concentration and transferring the fishes to the clean water, but was subsequently observed during 14 days. On the other hand, 2 months after the exposure to the sublethal concentration (1\% of $48 \mathrm{~h} \mathrm{LC}_{50}$ ), the erythrocyte AChE continued to be inhbited by as much as $54.6 \%$, which evidenced profound changes to have taken place in the affected fish organism.

Nikulina and Sokolskaja (1975) observed intensive haemopoietic processes in 10-days-old carp larvae exposed for 10 days to low $\left(0.001 \mathrm{mg} \mathrm{dm}^{-3}\right)$ concentrations of four organophosphate insecticides, the changes being evident from presence of immature blood cells; they concluded that the intensified erythro- and leukopoiesis are associated with mobilisation of defence mechanisms in the organism affected.

Lone and Javaid (1976) who analysed a short-term (up to 4 days) exposure of Channa punctatus to sublethal concentrations of three organophosphate pesticides, recorded a progressive decrease in the erythrocyte count, mean $\mathrm{MCH}$ value and blood cell diameter increasing at the same time. A total leukocyte count did not alter when influenced by malathion and methyl parathion, while the Lebaycid caused a leukocytopoenia. All the substances tested caused changes in the leukocyte pattern, involving a decrease in lymphocytes and monocytes.

Metelev (1972) observed highly intensified pathologic changes, both qualitative and quantitative, in the blood of all the species (Cyprinus carpio, Carassius carassius, Ctenopharyngodom idella, Hypophthalamichthys molitrix) exposed to sublethal concentrations of methylnitrophos, phosphamide, and trichlorometaphos-3. All these substances caused intensified degenerative changes in erythro-and leukocytes. Moreover, phosphamide was found to develope a decrease in the haemoglobin content as well as leukopoenia, while trichlorometaphos-3 caused ery thropoenia with hemolysis.

The paper by Metelev et al. (1977) is a continuation of the above-discussed study; the authors present toxic effects of the same three substances at normally-used concentrations. Degenerative and necrotic changes in erythro- and leukocytes were observed again, as was leukopoenia and an increase in immature erythrocyte counts.

No significant changes in activity of both the blood oxidoreductases were found in the present study. On the other hand, several authors report the contrary. Metelev (1972) found a $23-52 \%$ decrease in the blood peroxidase activity under the influence of 
sublethal concentrations of the organophosphate insecticides mentioned, accompanied by a decreased (by 18-41\%) oxygen demand, which, according to that author, evidences a lower level of redox processes in tissues and a reduction in the activity of respiratory enzymes. Thomas and Murthy (1976 a), experimenting with Clarias batrachus, observed a substantial inhibition of the liver and kidney catalase activities caused by phosphamidon: the in vivo inhibition was 30.9 and $28.5 \%$, respectively, while the insecticide tested in vitro caused a decrease by $53.9 \%$ in the liver homogenate and by $65.3 \%$ in the kidney one. In another experiment Thomas and Murthy (1976 b) analysed effects of monocrotophos, a organophosphate insecticide, used separately and combined with endrin and sevin, on Heteropneustus fossilis, and recorded a significant decrease in the liver and kidney catalase activities in all the experimental systems.

Referring to the results of haematologic assays obtained in this study in the experiments involving sublethal insecticide concentrations, the utility of haematologic indices in determining the organism's response to toxicants, organophosphate insecticides in particular, has been proven once again. Although, as it can be expected, the blood reaction was not so unambiguous as in the acute experiment, statistically significant differences with respect to the control gave evidence to the insecticide-induced changes. Infortunately, the question to what extent this effect does interfere with the regular function of the body cannot be answered. The analysis of qualitative changes in blood morphotic elements (Piotrowska, 1980, in preparation) and monitoring of changes in the blood (and also in the brain AChE activity) after the fish have been transferred to clean water are seemingly most promising in this context.

Another experiment performed was aimed at comparing two insecticides in terms of their inhibition power after a 24 -h exposure to concentrations corresponding to $50 \%$ of $24 \mathrm{~h} \mathrm{LC}_{50}$, as well as at observing the brain AChE recovery over 30 days following the cessation of the exposure (Fig. 1). CVP proves to be a much stronger cholinesterase inhibitor. This found reflection in both the AChE values directly after the exposure (62\% of the control and no reaction in the CVP- and BVP-affected fish, respectively) and in the changes of the enzyme activity during the post-exposure period.

The hydrolase activity in fishes exposed previously to sublethal CVP concentrations did not return to the normal level during the period of observations except for a few individuals showing the normal values after 24 and 30 days. The decrease in the AChE activity down to the minimum on the 4th (35\% of the control mean, which equals to an inhibition as high as 65\%) followed by a slow increase (the inhibition was about $50 \%$ after 6 and 12 days) to a level of about $70 \%$ after 24 and 30 days. Noteworthy is presence of the AChE inhibition delayed in time (after the cessation of the exposure), reported earlier by Weiss $(1959,1961)$, and also the fact that the enzyme remained less active by at least $50 \%$ over a prolonged period of time (from the 1st till 12th day). The first observation could be relevant for a diagnosis of the fish intoxication caused by the compound discussed by offering a possibility to detect an AChE inhibition in some time after the substance has leaked to the water, while the other proves a significant degree of toxicity 


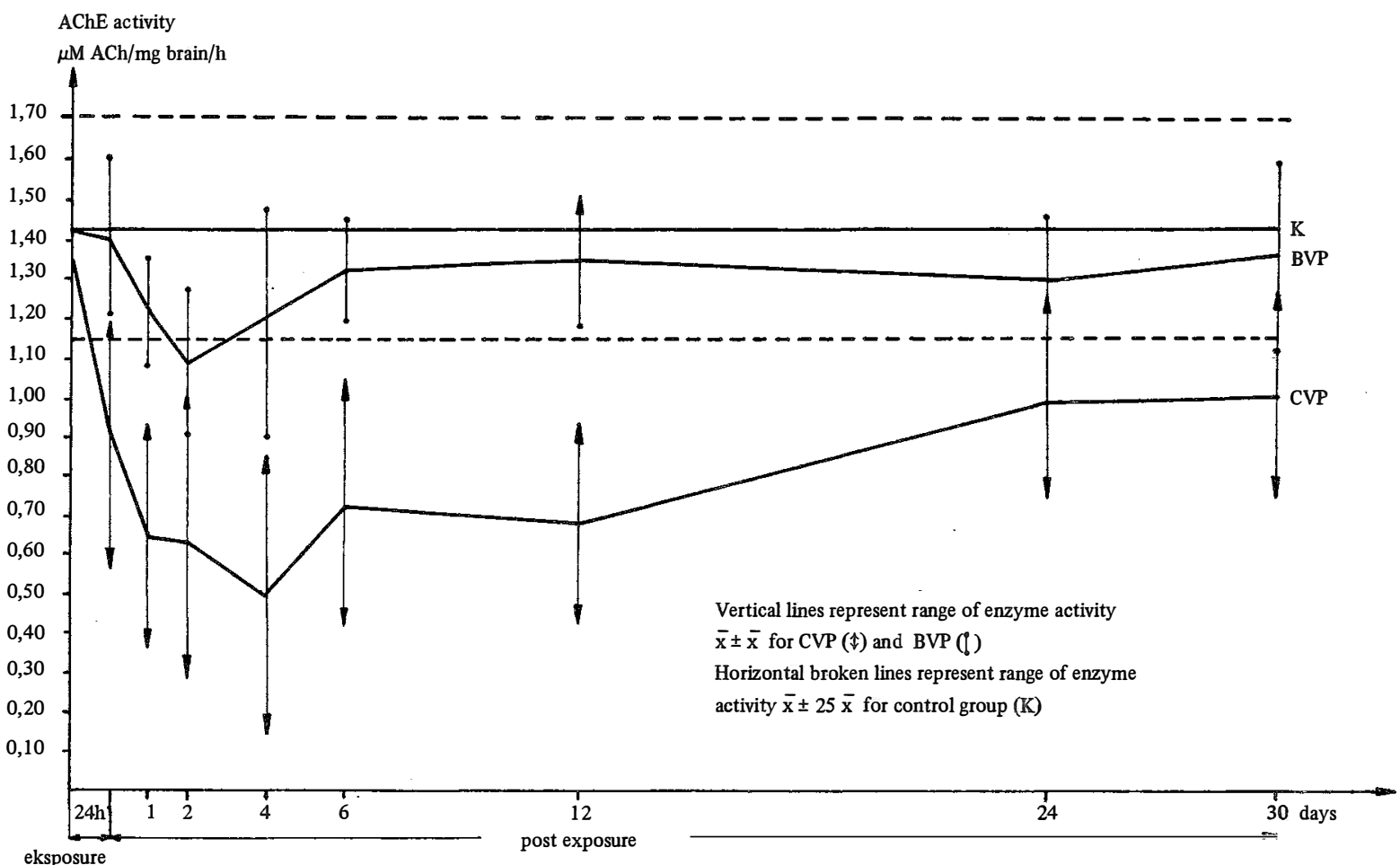

Fig. 1. Changes in brain acetylcholinesterase activity of rainbow trout (S. gairdneri Rich.) during recovery period 
of the compound, especially for the nervous system. Post and Leasure (1974) in their studies on the effect of sublethal concentrations of malathion on fishes recorded a considerable deterioration in rainbow trout motoric activity accompanying a 50\% reduction in the $\mathrm{AChE}$ activity, the physical activity index amounting to about $66 \%$ of the normal value. The authors emphasised the dangerous consequences of phenomenon the hazards involving a deterioration of such forms of activity as search for food, maintain position in running water, and avoidance of predators. The authors point a to prolonged time of recovery in all the species tested.

The AChE activity changes after the exposure to sublethal concentrations of BVP was much less affected. The $\mathrm{AChE}$ activity decreased to about $85 \% 1$ day after the exposure was completed. A slightly larger decrease was observed 2 days after the exposure, while after 4 days from the cessation an increase to the level recorded 1 day after the exposure was observed. 6 days after the exposure the $\mathrm{AChE}$ activity was normal again.

The brain AChE activity recovery in many fish species undergoing a short-term exposure to a large number of organophosphate pesticides was comprehensively studied by Weiss $(1958,1959,1961)$. He found the degree of inhibition to be a function of insecticide concentration, time of exposure, pesticide properties, and fish species. $\mathrm{He}$ presented some typical curves illustrating the $\mathrm{AChE}$ activity changes after the exposure and revealing considerable differences in recovery period. The delayed inhibition, which was sometimes associated with a delayed lethal effect as well as the examples of a prolonged $\mathrm{AChE}$ inhibition (no recovery after 20,30, and 40 days of observations), indicate that fishes are particularly jeopardized. In most cases, however, the enzyme activity did regain its normal values, which shows a fish organism to possess a developed faculty to protect itself against anti-cholinesterase substances.

\section{CONCLUSIONS}

1. The studies carried out on rainbow trout (Salmo gairdneri Rich.) showed CVP to be more toxic than BVP.

2. The brain acetylcholine hydrolase activity dynamics after the fish had been exposed to sublethal concentrations of the insecticides revealed a delayed anti-cholinesterase effect to appear, which was more intensive and of a longer duration in case of CVP.

3. Sublethal concentrations of the insecticides tested resulted in deleterious changes in the blood, some of them evidencing a mobilisation of the organism's defence system. BVP turned out to be more hazardous in this respect.

\section{REFERENCES}

Blaxhall, P.C., Daisley, K.W., 1973: Routine haematological methods for use with fish blood, - J. Fish Biol., 5: 771-781. 
Hestrin, S., 1949: The reaction of acetylcholine and other carboxylic acid derivatives with hydroxylamine, and its analy tical application, - J. Biol. Chem., 180: 249-261.

Kanaev, A.I., Grishchenko, L.I., Trondina, G.A., Verkhovski, A.P., 1977: Diagnostika otravlenii ryb ftalofosom, - Veterinariya, 10: 103-104. [in Russian].

Klontz, G.W., Smith, L.S.,1968: Methods of using fish as biological research subjects. In: W.I. Gay (Editor), Methods of animal experimentation., vol. III, Academic Press, New York-London, pp. 323-385.

Lone, K.P., Javaid, M.Y., 1976: Effect of sublethal doses of three organophosphorus insecticides on the haematology of Channa punctatus (Bloch), - Pakistan J. Zool., 8,1: 77-84.

Metelev, V.V., Osetrov, V.S., 1968: Nekotorye voprosy diagnostiki otravleniya ryb, - Veterinariya, 7: 68-70. [in Russian].

Metelev, V.V., 1971: Metodika opredeleniya toksikozov po peroksidaznoi aktivnosti krovi. In: N.S. Stroganov (Editor), Metodiki biologicheskikh issledovanii po vodnoi toksikologii, Naúka, Moskva: 73-76. [in Russian].

Metelev, V.V., 1972: Gematologicheskie i biokhemicheskie issledovaniya pri otsenke toksichnosti pestitsidov dlya ryb. - Tr. V.N.I.I. Vet. Sanit., 43: 227-232. [in Russian].

Metelev, V.V., Brichko, V.F., Korzhevenko, G.N., 1977: Ostatki nekotorykh FOS i vliyanie ikh na ryb, - Veterinariya, 4: 100-103. [in Russian].

Nikulina, S.S., Sokolskaya, N.P., 1975: Vliyanie nekotorykh pestitsidov na ontogenez karpa, Veterinariya, 7: 94-95. [in Russian].

Piotrowska, E. (in press): Effect of lethal concentrations of selected phosphoro-organic insecticides upon rainbow trout (Salmo gairdneri Rich.).

Post, G., Leasure, R.A., 1974: Sublethal effect of malathion to three salmonid species, - Bull. Environ. Cont. Tox., 12, 3: 312-319.

Rehnwoldt, R.E., Kelley, E., Mahonej, M., 1977: Investigation into the acute toxicity and some chronic effects of selected herbicides and pesticides on several fresh water fish species, - Bull. Environ. Cont. Tox., 18, 3: 361-365.

Thomas, P.C., Murthy, T.L., 1976a: Effect of phosphamidon on hepatic and renal catalase of freshwater bony fish, - Indian J. Fish., 21, 2: 594-597.

Thomas, P.C., Murthy, T.L., 1976b: Studies on the impact of a new organic pesticides on certain fish enzymes, - Indian J. Anim. Sci., 46, 11: 619-624.

Weiss, C.M., 1958: The determination of cholinesterase in the brain tissue of three species of fresh-water fish and its inactivation in vivo, - Ecology, 39, 2: 194-199.

Weiss, C.M., 1959: Response of fish to sub-lethal exposures of organic phosphorus insecticides, - Sew. Ind. Wast., 31, 5: 580-593.

Weiss, C.M., 1961: Physiological effect of organic phosphorus insecticides on several species of fish, Trans. Amer. Fish. Soc., 90: 143-152.

Weiss, C.M., Gakstatter, J.H., 1964: Detection of pesticides in water by biochemical assay, - J. Wat. Poll. Contr. Fed., 36, 2: 240-253.

Williams, A.K., Sova, C.R., 1966: Acetylcholinesterase levels in brain of fish from polluted waters, Bull. Environ. Cont. Tox., 1, 5: 198-204. 
Elena Piotrowska

\section{WPEYW SUBLETALNYCH STEZZ̊EŃ WYBRANYCH INSEKTYCYDÓW FOSFOROORGANICZNYCH NA PSTRĄGA TĘCZOWEGO SALMO GAIRDNERI RICH.}

\section{Streszczenie}

W warunkach laboratoryjnych przeprowadzono badania wpływu subletalnych stężeń chlorfenwinfosu i bromfenwinfosu na narybek pstrąga tęczowego (Salmo gairdneri Rich.). W pierwszym z doświadczeń eksponowano ryby przez dwa tygodnie w stężeniach insektycydów odpowiadających 5\% $96 \mathrm{~h} \mathrm{LC}_{50}$, po czym wykonywano analizy wybranych parametrów hematologicznych i enzymatycznych. W następnym doświadczeniu zastosowano ekspozycję $24 \mathrm{~h} \mathrm{w}$ stężeniach odpowiadających połowie wartości $24 \mathrm{~h} \mathrm{LC}_{50}$ i przeprowadzono badania zmian aktywności acetylocholinoesterazy mózgu po przeniesieniu ryb do czystej wody w okresie 30-dniowej obserwacji.

Uzyskane wyniki dostarczyły danych odnośnie różnic w mechanizmach toksycznego oddziaływania obu związków na pstrąga tęczowego. Wykazały silniejsze działanie antycholinoesterazowe chlorfenwinfosu, natomiast bromfenwinfos wywołał bardziej niekorzystny wpływ na krew obwodową. Stwierdzono zjawisko opóźnionego efektu antycholinoesterazowego, który przejawiał się spadkiem aktywności enzymu po skończeniu ekspozycji.

\section{Е. Пиотровска.}

ВЛИЯНИЕ НА РАДУЖННУО ФОРЕЛЬ (SA IMO GA IRDNERI RICHARDSON) СУБЛЕТАЛЬНБО КОНИЕНТРАЦИИЯ НЕКОТОРЫХ ФОСФОРООРГАНИЧЕСКИХ ИНСЕКТИЦИДОВ

$$
P \text { e s } x
$$

В лабораторных условия провели исследование влияния сублетальных кондентрации хлорфенвинфоса и бромфенвинфоса на мальков радухной форели (Salmo gairdneri Rich.). В первом опыте экспонировали рыб в течение 2 недель при концентрации инсектицидов соответствующией $5 \% 96$ час. IC 50 '

Одновременно проводили анализ некоторых гематологических и энзиматических параметров, В следующим опыте применили экспозицию 24 часа при концентрации соответствуще половине значения 24 час. IC 50 и провели исследование изменений активности ацетиль х холинэстеразы мозга после перенесения рыб в чистую воду. шри 30-ти дневном наблодении. На основании данных можно найти разницу. в механизме токсического действия указанных соединений на радужную форель. Хлорфенвинос имеет более сильное антихолинэстеразное действие а бромфенвинфос более отрицательно действовал на периферическую кровь о Напли явление более однозданного антихолинэстеразного эффекта, который проявлялся понияением активности энзима после окончания эксперимента.

Перевод: dr Józef Domagała 
Address:

Dr Elena Piotrowska

Akad. Roln.-Techn. Olsztyn

Wydz. Ochrony Wód i

Rybactwa Sródlądowego

Kortowo, bl. 37, p. 3

10-957 OLSZTYN

Polska (Poland) 